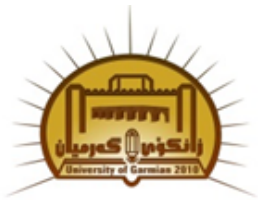

Available online at http://jgu.garmian.edu.krd

Journal of University of Garmian

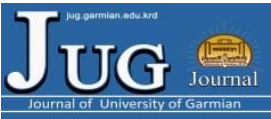

https://doi.org/10.24271/garmian.196225

\title{
A Stylistic Study of Katherine Mansfield's "Bliss"
}

\author{
Media Rafiq Majeed, Snoor Ismael Mahmood, Jwan Adil Mohammad \\ English department, College of Education , University of Garmian
}

Article Info

Received: May, 2019

Revised: June,2019

Accepted: June,2019

\section{Keywords}

Sty listics, Leech and Short's Model, Katherine Mansfield, Bliss.

Corresponding Author

jwan.adil@garmian.edu.krd

\begin{abstract}
This study is conducted to explore Mansfield's famous short story, "Bliss" on the basis of stylistic approach. To achieve this aim, it serves a wide range of linguistic data under stylistic categorizations to provide a scientific sight to text readings. In this way; it is noticeable that stylistics attempts to show that literature and linguistics are two complementary parts. Preparing concrete basements for literary criticism, stylistic studies reveal fingerprints of an author that makes the author unique and original. In this study, the short story "Bliss" written by the contemporary New Zealand author Katherine Mansfield is selected to be analyzed from the stylistic point of view under the categorizes of lexical category, grammatical category, figures of speech and cohesion to show the message that underlines the surface meaning.
\end{abstract}

\section{Stylistics: An overview}

Stylistics, or linguistic criticis $m$, is a way of interpreting texts by systematically analyzing linguistic forms and features within a text (Toolan, 1990: 28). A linguist uses linguistic evidence to interpret meanings. Stylistics attempts to explain scientifically the relationship between language styles and aesthetic values that are created through the analyses of certain linguistic forms within a text (Leech and Short, 1981: 11). Leech (1969) explains that linguistic deviation can be described as an unexpected irregularity, which is important tangible evidence that contributes to the stylistic approach.

Widdows on (1975:4) defines stylistics as follows: "By _stylistics' I mean the study of literary discourse from a linguistic orientation and I shall take the view that what distinguishes stylistics from literary critic is $m$ on the one hand and linguistics on the other is that it is essentially a means of linking the two.....stylistics, however, involves both literary critic is $\mathrm{m}$ and linguistics, as its morphological makeup suggests: the style component relating it to the former and the istics " component to the later."

Abrams (1993) states that "[Stylistics] insists on the need to be objective by focusing sharply on the text itself and by setting out to discover the "rules" governing the process by which linguistic elements and patterns in a text accomplish their meanings and literary effects." (284). Stylistics mainly explains the relationship between the text and its context; its aim is "...to use the analys is to promote understanding of the literary purposes and functions to which 
particular uses of language are put." (Carter \& Long, 1992: 121)

Verdonk(2002:4) defines stylistics as -the analysis of distinctive expression in language and the description of its purpose and effectll. Bradford (1997:1) says that stylistics is -an elusive and slippery topic every contribution to the vast, multifaceted discipline of literary studies will involve an engagement with style".

\section{Model of Stylistic Study}

Stylistic model is a framework of analyzing a text that is comprised of different linguistic categories. The model is underpinned by a set of linguistic levels that enables us to "explain how we process and understand various patterns in language" (Simpson, 2004: 3). It explains a sufficient and practical method of analyzing the style of a text to reach the outcome and finding of the "artistic principles underlying a writers choice of language" (Leech \& Short, 2007: 60) Accordingly( Jeffries and Mclntyre,2010)describe stylistic analysis as an application of levels of language on a literary text "to investigate from phonology to the semantics of literary text"(12). Therefore, stylistic model enables us to collect the data from a text in a systematic way based on different linguistic levels that co-exist with the others. Similarly, Geoffrey Leech and Mick Short in their book entitled Style in Fiction, formed a checklist and a method of stylistic analysis based on four major categories: Lexical categories, grammatical categories, figure of speech, cohesion and context. Along with semantic categories incorporated into other linguistic levels, since the analytical connection between linguistic form and literary function is based on personal discovery and opinion of the reader. The model is an aid to find out that relationship between language and artistic function of the language used.

\section{* Leech and Short's Model}

\section{Lexical Categories}

Throughout the reading of the text of the short story "Bliss" one of the significant stylistic features is the choice of words that enrich and enhance the way of conveying the main idea of the story. Using the words, that are suggestive of hidden meaning and feeling, encourages intellectual interpretation and deep reading of the main concept of the story. The words, as analy zed on the lexical level, show the writer's artistic style to express the main theme of her short story. As the title suggests, the story is concerned with the feeling of joy in one day of the life of a thirty years old Bertha Young who is the protagonist of the story. The story starts with the description of the feeling of the main character who is a lady, mother and wife. The story opens with:

ALTHOUGH Bertha Young was thirty she still had moments like this when she wanted to run instead of walk, to take dancing steps on and off the pavement, to bowl a hoop, to throw something up in the air and catch it again, or to stand still and laugh at-nothing-at nothing, simply.

What can you do if you are thirty and, turning the corner of your own street, you are overcome, suddenly by a feeling of blissabsolute bliss!-as though you'd suddenly swallowed a bright piece of that late afternoon sun and it burned in your bosom, sending out a little shower of sparks into every particle, into every finger and toe?...

$\mathrm{Oh}$, is there no way you can express it without being "drunk and disorderly" ? How idiotic civilisation is! Why be given a body if you have to keep it shut up in a case like a rare, rare fiddle? (Mansfield,1918:1)

The description of the feeling of the lady is not direct, but it is intellectualized and envisioned through the act of perception by making frequent use of dynamic verbs that allude to action and movement, such as "run, walk, dancing, bowl, throw, catch, turning, etc". But the verbs are preceded by a stative verb "want" it indicated that the actions are not performed in reality, but rather imagined and dreamed in her mind. It shows the state of a lady who wants to enjoy "absolute bliss" in a society that confines her freedom and desire due to the social values of that time. This idea is reinforced by using concrete nouns that denote places such as "pavement, corner, street, etc"; it shows the life in the urban area. Another, related tendency, is the use of abstract noun that are referring to society and psychology of the individual such as "feeling, blis s, civilization" the 
words implicitly show the social constraints and customs that restrict and confine the life of a woman. The convention of their social class imprisons her feeling and she cannot freely express her emotion and feeling. Again the choice of the adverb "simply" and conjunctions such as "although" and adjective "drunk and disorderly" with the verbs such as "there is no way to express" denotes that enjoying a childish joy, such as "laughing- at nothing- at nothing simply" is a kind of shame for a lady aged thirty and that there are certain rules that determine the behavior of the mature individuals especially females. Verbs such as "overcome, swallowed, burned, shut up" suggest the meaning of suppressing the feeling and the persecution of wo man and the lack of freedom.

It was dusky in the dining-room and quite chilly. But all the same Bertha threw off her coat; she could not bear the tight clasp of it another moment, and the cold air fell on her arms.

But in her bosom there was still that bright glowing place-that shower of little sparks coming from it. It was almost unbearable. She hardly dared to breathe for fear of fanning it higher, and yet she breathed deeply, deeply. She hardly dared to look into the cold mirrorbut she did look, and it gave her back a wo man, radiant, with smiling, trembling lips, with big, dark eyes and an air of listening, waiting for something ... divine to happen ... that she knew must happen . . . infallibly. (Mansfield,1918:1)

Similarly, in the passages that describe the feeling and thought of Bertha, the feeling of discomfort is sensed through using sensory words and verbs that show the psychological state and underpinned by the use of adjectives that show the physical sense and touch such as "chilly, dusky, tight, cold" that describe the sense on their body such as "arm, finger, toe, bosom". Verbs such as "dared to breath" "dared to look" "waiting for something divine to happen" "breathe" show the state of being powerless and helpless and the sense of discomfort and unpleasant situation that the lady lives in. Adverbs such as "almost, hardly, deeply, infallibly" show the intensity of the situation.
When the setting or the palace that she lives in is described, the writer makes excessive use of physical concrete nouns such as "tangerines, apples, strawberry, pears, carpet, table etc. that are accompanied by adjectives particularly adjectives of color that help us to visualize the scene. Adjectives such as "pink, yellow, white, silver, purple, blue etc. have been used to shape the world in which she can find her bliss. As the authorhas written:

There were tangerines and apples stained with strawberry pink. Some yellow pears, smooth as silk, some white grapes covered with a silver bloom and a big cluster of purple ones. These last she had bought to tone in with the new dining-room carpet. Yes, that did sound rather far-fetched and absurd, but it was really why she had bought them. She had thought in the shop: "I must have some purple ones to bring the carpet up to the table." And it had seemed quite sense at the time.(Mansfield,1918:2)

Additionally, arranging the colorful table and creating such a colorful vision in which she is overjoyed, the writer shows the mood of the main character in a particular moment through using words such as " This, of course, in her present mood, was so incredibly beautiful.... She began to laugh". The writer through a careful use of words shows us the notion that women are suffering psychologically because of their gender inequality in the society.

She also makes use of nouns that refer to entities that exist in the natural world such as animals like "cat, dog," plant and natural foods like " tree, bud, petal, flower, fruit, bloom, tulips etc. and some other nouns such as sky, moon, garden, sea, air , lawn, dusketc."

The windows of the drawing-room opened on to a balcony overlooking the garden. At the far end, against the wall, there was a tall, slender pear tree in fullest, richest bloom; it stood perfect, as though becalmed against the jadegreen sky. Bertha couldn't help feeling, even from this distance, that it had not a single bud or a faded petal. Down below, in the garden beds, the red and yellow tulips, heavy with flowers, seemed to lean upon the dusk. A grey cat, dragging its belly, crept across the lawn, 
and a black one, its shadow, trailed after. The sight of them, so intent and so quick, gave Bertha a curious shiver.

And the two women stood side by side looking at the slender, flowering tree. Although it was so still it seemed, like the flame of a candle, to stretch up, to point, to quiver in the bright air, to grow taller and taller as they gazed-almost to touch the rim of the round, silver moon.

How long did they stand there? Both, as it were, caught in that circle of unearthly light, understanding each other perfectly, creatures of another world, and wondering what they were to do in this one with all this blissful treasure that burned in their bosoms and dropped, in silver flowers, from their hair and hands? (Mansfield, 1918:4,9)

Turning to the natural world shows the brutality of life in the city and escaping from reality and even from the confined life of their home especially when they look outside and feel the existence of another world. When they look outside from the window they imagine another world in which woman are free from conventions of the city life and enjoy an imaginary happiness. The above passages are preceded by the adverb of place "There!" and followed by the adverb of time "for ever- for a moment? It means that they are seeking a place and time in which they can enjoy their lives freely. It implies the meaning of being victims at that time in that society.

When the feeling of Bertha is described as a mother, verbs are of significant use also. Verbs that allude to psychological fee ling and speech act are used together such as "wanted to ask" , then they are followed by the negative form of " $\mathrm{did}$ not dare" and verbs of perception "stood watching" and the baby is described as being "kept" in a anotherwoman's arms.

Bertha wanted to ask if it wasn't rather dangerous to let her clutch at a strange dog's ear. But she did not dare to. She stood watching them, her hands by her side, like the poor little girl in front of the rich girl with the doll.[...] How absurd it was. Why have a baby if it has to be kept-not in a case like a rare, rare fiddle-but in another woman's arms? (Mansfield, 1918: 2)
These lines show the relationship among people of the middle class. They feel alienated as though there is a kind of distance between them despite of living together. As the writer describes the family she uses simple direct descriptions with colloquial language and words such as "good pals" she shows imperfect familial relationship of that time and love between wife and husband. She writes:

Really-really-she had everything. She was young. Harry and she were as much in love as ever, and they got on together splendidly and were really good pals. She had an adorable baby. They didn't have to worry about money. They had this absolutely satisfactory house and garden. And friends-modern, thrilling friends, writers and painters and poets or people keen on social questions-just the kind of friends they wanted. ( Mansfield,1918:5)

Through the story the verbs that suggest activities and move the action of the story are frequently verbs such as "drinking, eating, smoking, having party, meeting friends, looking at, speaking, with nouns such as food, guest, coffee, table, drawing room. These verbs and nouns suggest the activities that cause the change of mood and the emotional reaction and hence, the inner struggle within the psyche of the character and finding a way to express it and get rid of it.

\section{Grammatical Categories}

Grammatical category focuses on variations in sentence structure, punctuation and sentence length enriching the story linguistically. Variations at grammatical phase need to be examined for the aim of revealing power of language by which the author creates the aesthetic value of her literary work. "Bliss" exemplifies many grammatical variations which is very critical for building-up the process of a short story. The story begins with a paragraph including many imperative sentences:

"Although Bertha Young was thirty she still had moments like this when she wanted to run instead of walk, to take dancing steps on and off the pavement, 0.10to bowl a hoop, to throw something up in the air and catch it again, or to stand still and laugh at - nothing - at nothing, simply." (Mansfield, 1918:1) 
According to Andreson(2014-1)a sentence is the highest rank of grammatical construction. It is a complete set of words that conveys meaning. A sentence can communicate or a statement (I am studying) ora commend(Go away) or an exclamation (I'm so excited!) or a question (What time is it?) A sentence is composed of one or more clauses. A clause contains a subject and verb.

Most of the sentences of the short story "Bliss" fall into the latter two types, namely, exclamation andquestion. But it is particularly noteworthy that this textual web, generally woven out of declarative and commentary sentences, is also densely interspersed with statement sentences. Here is an example from the story:

$\mathrm{Oh}$, is there no way you can express it without being "drunk and disorderly" ? How idiotic civilization is! Why be given a body if you have to keep it shut up in a case like a rare, rare fiddle?

"No, that about the fiddle is not quite what I mean," she thought, running up the steps and feeling in her bag for the key-she'd forgotten it, as usual-and rattling the letter-box. It is not what I mean, because -Thank you, Mary"-she went into the hall. "Is nurse back?

"Yes, M'm." "And has the fruit come?" "Yes, M'm. Everything's come." (Mansfield, 1918:1)

In terms of syntactical complexity, Mansfield's style is also drastically distinguished from those of her contemporaries. Her syntax is generally simple, by no means intricate. The author uses question/ns, imperatives, and exclamation and declarative sentences. This story is rich in case of syntactic features. It has been written in simple mode but the writer has written some complex lines. There is usage of nouns, pronouns, adjectives, verbs, adverb, and articles.

Although this short story is full of details and imagery yet the choice of vocabulary is simple and unique, it does not only give vibrancy to the text but also makes it deeper and explicit at the same time. The language and expression are colloquial and belongs to everyday language.

The story is reflection of emotional situations of the characters and also about their physical outlooks. The usage of adjectives makes the text more attractive and writer reveals most of the themes and the physical conditions through adjectives. The examples are like cold, dark, , white deep, beautiful girl, happy, writer, chill and lazily, poor little girl and etc.....

Verbs play conspicuous role in giving sense to various events and circumstances which have been used in this short story .Stative verbs are helpful to know the moods of main characters. Verbs are mostly about doings and physical movements. The use of auxiliaries is also apparent. Transitive verbs and helping verbs. There is a mass use of conjunction that means joining together, a word which is used to connect sentences as then, and, but, if as, as soon as, though -yet, neither-nor etc...

Another important point about grammatical varieties of the story is the utilization of italics. She uses less italic in "Bliss", yet grammatical deviation by italics occurs at the critical linguistic components of the story. They give direct messages to the reader where they are put into practice.

Yet, another examined grammatical variation in the story the usage of dots (...) and dashes (-). Likely, although they are not much used in the story, Mansfield gives them important functions for instance, when sentences including dots, are analyzed, it is clear that the author aims to raise the reader's curiosity or gives freedom to the readers to fill in the blanks as they wish this is on one hand, on the other hand, dashes are used to give detailed information about the characters, their momentary moods and setting. Thus, she accomplishes the task of drawing a realistic picture on the reader's mind and putting them into the story in a clear way:

" ... Then you can come part of the way in my taxi."

"He made a point of catching Bertha's heels with replies of that kind ... "liver fro zen, my dear girl," or "pure flatulence," or "kidney disease," ... and so on. For some strange reason Bertha liked this, and almost admired it in him very much.

But then, then - "My dear," said Mrs. Norman Knight, "you know our shame. We are the victims of time and train. We live in Hampstead. It's been so nice."

Bertha knew that he was repenting his rudeness she let him go. What a boy he was in some ways so impulsive - so simple.( Mansfield, 1918: 11 ) 


\section{Figures of Speech}

The story "Bliss" is filled with figures of speech. The author in her writing style uses a lot of distinctive features of figurative language such as metaphors, similes, repetition, alliteration and others.

1. Alliteration: is a literary term used widely in literature. It is the repetition of the initial consonant sounds or letters (Auger,2010:11) In "Bliss" Katherine Mansfield focuses a lot on alliteration and the followings are some examples from the story: "drunk", "disorderly" and "dizzy" start with same consonant /b/; "full" and "fed" start with /f/, "cool" and "collected" start with /c/, "fried" and "fish" start with /f/. More interesting to observe is the coupling of "time" and "train", "sleepy" and "smile". Other examples of alliteration exist in many other parts of the story.

2. Repetition: is a literary device used when the same words, phrases, sentences or clauses are used more than one time in the same sentence or line. The author in "Bliss" does not neglect the use of sound effects and the repetition of words or letters in impressing the readers.

Let's take some examples from the story,in paragraph one and two for instance: "laugh atnothing-at nothing, simply" and "suddenly by a feeling of bliss-absolute bliss" (Mansfield, 1). The two words "laugh" and "bliss" describe Bertha's feeling that is she really enjoys her life in the beginning of the story. No doubt, this feeling of great happiness will be changed at the end.

The next pages in "Bliss" show more examples of repetition, for instance in page two: "No, no. I am getting hysterical" and "like a rare, rare fiddle". In page five there are other examples like: "Really- really - she had everything", "I am absurd. Absurd", "Why! Why! Why is the middle class so stodgy- so utterly without a sense of humour!" and "this is a sad, sad fall", "I am sure there is oftenoften!', "all in silver, with a silver fillet binding her pale blonde hair", "what was there in the touch of that cool arm that could fan-fan start blazing-blazing- the fire of bliss", "they were dears-dears", "this does happen very, very rarely between women", "but now- ardently! ardently!", "so impulsive-so-simple" and finally "your lovely pear tree-pear treepear tree!".

3. Symbol: is another important device. It is an object or action that stands for another so as to give an entirely different meaning from its origin. Moreover, it represents something else. When the reader comes across "Bliss", he will find out that it is a story filled with symbolism. The most important and complicated symbol is the "pear tree" which is located in the garden of Bertha's house. Firstly, this symbol represents Bertha herself when she believes that "it is a symbol of her own life" (Mansfield, 4). For the dinner party, Bertha dresses like the pear tree by wearing a white dress, a string of jade beads, green shoes and stockings. This proves that there is a great connection between Bertha and the tree. Secondly, the pear tree can be the symbol of awakening of her sexuality near the end of the story. Another important symbol in the story is the rare fiddle. Bertha Young views her body and her lifestyle just like a rare fiddle and that she should enjoy her life. So the rare fiddle is just a way of expressing her life by saying she has the life that people want, but she feels trapped inside.

In the story there are many other important symbols, for instance: the sun and the moon. The sun is the symbol of life, strength, growth and health. In the classical tradition, people believe that sun is a god and it should be worshiped while they thought that the moon is related to the feminine and as women it goes through phases (Ferber, 2007: 131). In the story, the moon is related to Bertha's instability that went through different phases. Also there is another symbol that is the silver color; it represents the feelings of Bertha Young that she cannot find the words to explain. There are other minor symbols in the story such as the "monocle" that is associated with wealth and power, "cigarette" on one hand it is a symbol of confusion and on the other hand it may represent relaxation. Finally, there is the ash symbol that represents the filthy side of society. 
4. Metaphor: is a major type of figures of speech in which a word or phrase is applied to an object or action so as to make a comparison between their similarities. One of the first images in the story is "a shower of sparks" and it can be related to the image of fire. In "Bliss" the writer mentions sparks more than one time. Ferber (2007) states that fire is essential to the life of human being and it can be in different forms and spark is one of these forms. In the story, Bertha is extremely unable to find the words to explain her great happiness or bliss. Another important metaphor in the story appears in this sentence: "And down she crouched by the fire again. She was always cold. Although there was a fire but Bertha still feels cold. Another metaphorical example is "we are the victims of time and train". Moreover, "Miss Fulton laid her moonbeam fingers on his cheeks and smiled".

5. Simile: is another type of figures of speech that involves the direct comparison of two different things. The sentence should contain (as or like) so as to improve that the sentence is simile.(Cuddon,1998:830) The comparison enables the readers to have a clear picture of the characters and actions in the story. The followings are some examples from the story: "If you have to keep it shut up in a case like a rare", "Some yellow pears, smooth as silk", "Her hands by her side like the poor little girl","Cold like all blonde women","She did looklike a very intelligent monkey","They were like little dangling nuts","Green and cold like the eyelids","The backs of the chairs shaped like frying-pans".

6. Quasi simile: this is where the words (as or like) are implied but are not part of the figures of speech. The followings are some examples: "Mrs. Norman Knight, who was taking off the most amusing orange coat with a procession of black monkeys round the hem and up the fronts" (5). Another example is "he really was a most attractive person. But so was Face, crouched before the fire in her banana skins" (6). "Her heavy eyelids lay upon her eyes and the strange, half smile came and went upon her lips (7).

\section{Cohesion}

In order to make a good piece of writing, cohesive devices are needed. The cohesive devices such as lexicon and reference are used to connect parts of short stories to make unity in the whole story. Having good coherence in a writing project means that your ideas stick together and flow smoothly from one sentence to the next. Therefore, readers of the work can easily understand what the writer want ideas to convey. Without cohesion, written can seem variably and not connected. Lacking of coherence can lead the readers to confusion and give them difficulties to comprehend the work. Writing sentence was coherent, when the sentence is related together. In "Bliss", the cohesive devices used by the author are very useful and helpful in analyzing the story. There are five cohesive devices used in "Bliss", which are, transition words, order, repetition of keywords and references too. A written work without any use of cohesive device can cause confusion to the readers. They may not know the main point of the story and be confused by the unclear plot if there is no device at all.

Examples include: Bertha wanted to ask if it wasn't rather dangerous to let her clutch at a strange dog's ear. But she did not dare to. She stood watching them, her hands by her side, like the poor little girl in front of the rich girl with the doll(Mansfield:2).

"No, no I am getting hysterical.(2) Why! Why! Why! is the middle class so stodgy-so utterly..(5) And transition words such as, thus, therefore; due to, although etc....

Repetition of key words throughout the story such as bliss, pear tree, fire, spark and etc.

\section{Conclusions}

Throughout the theoretical background of stylistics and analyzing Katherine Mansfield's Short story, "Bliss" on different levels of language possesses a very unique stylistic feature which can be jotted down as:

1- When she writes about the feeling of the character, she makes use of lexical words mainly verbs and adjectives and nouns to express the feeling and mood of the character in 
a combing mixture of stative and dynamic verbs in the same sentence. The adjectives are mostly portrayal of the scene to create the environmental images of the surrounding.

2- The writer is stick to complex sentences to show the instability of the mental state of some characters which shows the fragmentation of the distorted dream.

3- Concerning the figurative language, each of repetition, alliteration, simile, and metaphor has been utilized for the sake of displaying the notion of the short story that is non-convincing life of woman due to social conventions. She also makes use of symbolic language to depict the life that she wants to have and satirize the life that she has.

4- She draws her idea through dialogues among the characters more than the plain narrative technique in spite of her using of outstanding sketch of the plot.

\section{References}

1- Abrams.M.H. (1993).A Glossary of Literary Terms: Sixth Edition. Harcourt Brace Jovanovich College Publishers.

2- Auger, Peter.(2010). The Anthem Dictionary of Literary Terms and Theory. New York: Anthem Press.

3- Bradford, Richard.(1997). Stylistics, London: Routledge.
4- Carter, R. \& Long, M. N. (1991).Teaching Literature. Hong Kong: Longman.

5- Cuddon, J.A. (1998). Dictionary of Literary Terms \& Literary Theory, London: Penguin

6- Jeffries, Lesley\& Dan Mclyntyre.(2010) Stylistics. Cambridge: Cambridge University Press.

7- Leech, G. N. and M. Short. (1981). Style in fiction: A linguistic introduction to English fictional prose. London: Longman.

8- Leech, G. N. and M. Short. (2007). Style in Fiction: A Linguistic introduction to English Fictional Prose. London: Longman.

9- Mansfield, Katherine. (1918) "Bliss" www.katherinemans fields ociety.org

10- Michael, Ferber. (2007). A Dictionary of Literary Symbols. Cambridge: Cambridge University Press.

11- Simpson, P. (2004). Stylistics: A resource book for students. London: Routledge.

12- Toolan, M. J. (1990). The Stylistics of Fiction: A Literary-linguistic Approach. London: Routledge.

13- Verdonk, Peter. Stylistics, Oxford: Oxford University Press, 2002.

14- Widdowson, H.G. (1975). Stylistics and the Teaching of Literature.Longman. 


\section{"The mean of the questionnaire "}

\begin{tabular}{|c|c|c|}
\hline Level & $\begin{array}{c}\text { Mean of the class } \\
\text { observation }\end{array}$ & Indication \\
\hline 2 & 1.8364 & $\begin{array}{l}\text { Pedagogical grammar should be taught for three years in } \\
\text { college. }\end{array}$ \\
\hline 3 & 2.4364 & Descriptive grammar should be taught for three years \\
\hline 4 & 1.2182 & Grammar is very much important for EFL learners \\
\hline 5 & 1.47 & $\begin{array}{l}\text { Grammar will enhance students' achievements in the } \\
\text { English language }\end{array}$ \\
\hline 6 & 1.47 & $\begin{array}{l}\text { Grammatical structures have so much significant in } \\
\text { speaking/writing skills }\end{array}$ \\
\hline 7 & 2.05 & Students value grammar lesson \\
\hline 8 & 2.51 & $\begin{array}{l}\text { Eclectic approach is the best approach for teaching } \\
\text { grammar. }\end{array}$ \\
\hline 9 & 2.22 & Deductive approach motivates students \\
\hline 10 & 2.16 & $\begin{array}{l}\text { Deductive approach considers as an effective approach for } \\
\text { teaching English grammar }\end{array}$ \\
\hline 11 & 1.87 & Inductive approach fits good learners \\
\hline 12 & 1.87 & $\begin{array}{l}\text { Inductive approach is an effective approach for teaching } \\
\text { English grammar. }\end{array}$ \\
\hline 13 & 2.07 & $\begin{array}{l}\text { Inductive approach offer more advantages over deductive } \\
\text { approach. }\end{array}$ \\
\hline 14 & 1.85 & $\begin{array}{l}\text { Differences could be found between both deductive and } \\
\text { inductive approaches. }\end{array}$ \\
\hline 15 & 1.96 & Rule explanation in grammar has a good impact on students. \\
\hline 16 & 2.55 & $\begin{array}{l}\text { Translating grammatical features from mother tongue to the } \\
\text { target language and vice versa has a bad impact on students }\end{array}$ \\
\hline 17 & 2.02 & $\begin{array}{l}\text { Teaching articles through using grammatical worksheets is a } \\
\text { good way of teaching. }\end{array}$ \\
\hline 18 & 1.95 & $\begin{array}{l}\text { Giving homework and self-study are good ways of teaching } \\
\text { grammar }\end{array}$ \\
\hline 19 & 1.64 & $\begin{array}{l}\text { Teaching grammar through a generative situation is a good } \\
\text { way of teaching. }\end{array}$ \\
\hline 20 & 1.62 & $\begin{array}{l}\text { Teaching grammar through minimal sentences pairs is a } \\
\text { good way of teaching }\end{array}$ \\
\hline 21 & 1.76 & $\begin{array}{l}\text { Teaching grammar by using concordance data is a good way } \\
\text { of teaching }\end{array}$ \\
\hline 22 & 2.31 & $\begin{array}{l}\text { It is difficult for teachers to explain the grammar lesson only } \\
\text { using target language due to students' understandings }\end{array}$ \\
\hline 23 & 1.62 & $\begin{array}{l}\text { Teachers face difficulties because of students' poor } \\
\text { background in English grammar }\end{array}$ \\
\hline 24 & 2.33 & $\begin{array}{l}\text { Lecturers are facing difficulties in making learners apply } \\
\text { grammatical knowledge to communicate }\end{array}$ \\
\hline 25 & 2.24 & $\begin{array}{l}\text { It is difficult for teachers to use extra references due to the } \\
\text { shortage of time. }\end{array}$ \\
\hline 26 & 2.16 & $\begin{array}{l}\text { Teachers face difficulties using the inductive approach due } \\
\text { to all the heavy demands. }\end{array}$ \\
\hline 27 & 2.24 & $\begin{array}{l}\text { Deductive approach causes difficulties for the teachers due } \\
\text { to all the responsibilities put on the lecturers. }\end{array}$ \\
\hline
\end{tabular}




\section{"The results of the class observation"}

\begin{tabular}{ccccccccc} 
Q & \multicolumn{2}{c}{ Yes } & \multicolumn{2}{c}{ No } & & \multicolumn{2}{c}{ Total } \\
& Frequency & Percent & Frequency & Percent & Frequency & Percent & Frequency & Percent \\
\hline 1 & 5 & $50 \%$ & 5 & $50 \%$ & 0 & $0 \%$ & 10 & $100 \%$ \\
2 & 4 & $40 \%$ & 1 & $10 \%$ & 5 & $50 \%$ & 10 & $100 \%$ \\
3 & 3 & $30 \%$ & 2 & $20 \%$ & 5 & $50 \%$ & 10 & $100 \%$ \\
4 & 6 & $60 \%$ & 4 & $40 \%$ & 0 & $0 \%$ & 10 & $100 \%$ \\
5 & 2 & $20 \%$ & 4 & $40 \%$ & 4 & $40 \%$ & 10 & $100 \%$ \\
6 & 3 & $30 \%$ & 3 & $30 \%$ & 4 & $40 \%$ & 10 & $100 \%$ \\
7 & 1 & $10 \%$ & 9 & $90 \%$ & 0 & $0 \%$ & 10 & $100 \%$ \\
8 & 1 & $10 \%$ & 0 & $0 \%$ & 9 & $90 \%$ & 10 & $100 \%$ \\
9 & 2 & $20 \%$ & 8 & $80 \%$ & 0 & $0 \%$ & 10 & $100 \%$ \\
10 & 9 & $90 \%$ & 1 & $10 \%$ & 0 & $0 \%$ & 10 & $100 \%$ \\
11 & 9 & $90 \%$ & 1 & $10 \%$ & 0 & $0 \%$ & 10 & $100 \%$ \\
12 & 8 & $80 \%$ & 2 & $20 \%$ & 0 & $0 \%$ & 10 & $100 \%$ \\
13 & 0 & $0 \%$ & 5 & $50 \%$ & 5 & $50 \%$ & 10 & $100 \%$ \\
14 & 2 & $20 \%$ & 4 & $40 \%$ & 4 & $40 \%$ & 10 & $100 \%$ \\
15 & 5 & $50 \%$ & 1 & $10 \%$ & 4 & $40 \%$ & 10 & $100 \%$ \\
\hline
\end{tabular}

